\title{
Assessment and Management of Hurricane Damaged Timberland ${ }^{1}$
}

\author{
Alan Long, Jarek Nowak, Chris Demers, Rick Williams, Nicole Strong, Jib Davidson and John \\ Holzaepfel $^{2}$
}

The 2004 hurricanes damaged timberland from one end of Florida to the other. When hurricane- or tropical storm-force winds rip through forestland, the remaining twisted, broken and damaged timber is no longer the same merchantable product as it was before the storm. In addition to timber value and infrastructure losses, many forest landowners are also concerned about potential problems, such as bark beetles and wildfire, which may add to their woes in coming months. Every year, southern timberland is damaged by hurricanes, ice storms, or tornados somewhere in the region. In response, a variety of information sources have been developed to address the many issues associated with such damage. This fact sheet summarizes information and guidelines from these sources, with a focus on Florida. It provides guidance to forestland owners for assessing severe storm damage, handling salvage operations and timber sales, minimizing potential impacts of other disasters after the storm, dealing with financial issues such as income tax casualty losses, and altering management plans. The references listed at the end may provide landowners with additional information relevant to their particular situation (see Figure 1).

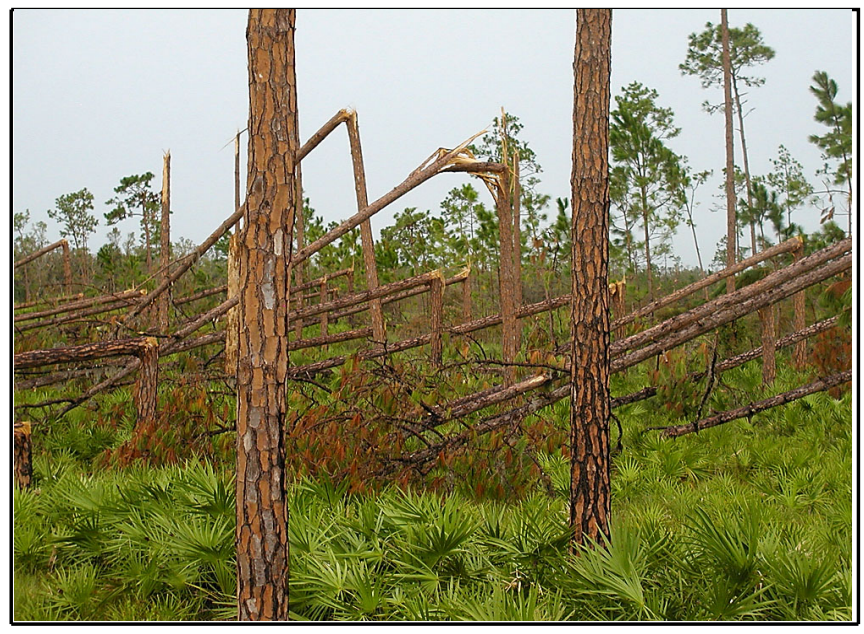

Figure 1. Hurricane-force winds broke these pine stems in Central Florida. Credits: John Holzaepfel (2004)

1. This document SS-FOR 22, one of a series of the School of Forest Resources and Conservation, Florida Cooperative Extension Service, Institute of Food and Agricultural Sciences, University of Florida. First published in January 2005. Funding for the production of this publication is provided by the USDA Forest Service through the Florida Department of Agriculture and Consumer Services Division of Forestry. Please visit the EDIS Web site at http://edis.ifas.ufl.edu.

2. Alan Long, Associate Professor, Jarek Nowak and Rick Williams, Asssistant Professors, and Chris Demers, Forest Stewardship Coordinator, School of Forest Resources and Conservation, Cooperative Extension Service, Institute of Food and Agricultural Sciences, University of Florida, Gainesville, FL 32611. Nicole Strong, Extension Specialist, Oregon State University, Corvallis, OR 97331. Jib Davidson, Manager, Columbia Timber Company, Gainesville, FL 32609. John Holzaepfel, Forester, Natural Resources Planning Services, San Antonio, FL 33576. 


\section{Sources for Assistance}

You do not have to deal with your losses alone. However, recognize that most of the sources described below are limited in the number of people they can help, and working with your neighbors or doing your own research may provide a good first step until other help is available.

\section{Financial Assistance}

Until recently, none of the disaster recovery programs administered by the federal government included forestry or timberland. Timberlands under the Conservation Reserve Program (CRP) may qualify for replanting cost-share assistance according to contract stipulations. Since timber is not an annual crop, landowners that grow trees have not been eligible for federal crop insurance like many agricultural commodities. Nor did the original emergency relief funds from the federal government include allocations to help timber owners. However, the emergency disaster relief-funding package signed by the President on October 22, 2004 includes $\$ 25$ million for assistance to family forest owners in the Southeast, of which a portion will come to Florida and be administered by the Farm Service Agency. The bill also included $\$ 40$ million specifically for Florida forest recovery programs, of which $\$ 8$ million is to help landowners with fire mitigation and reforestation. Funds will be administered by the Division of Forestry, but the exact rules for how these funds will be distributed may not be finalized before early in 2005. To prepare for this source of assistance as well as insurance or tax issues, take pictures of the damaged stands in order to document the types of damage and the size, age and types of trees. Also, compile any records of expenses and treatments in those stands since they were established (to document your basis for taxes), and keep any records of salvage sales that you are able to complete or attempted to make.

\section{Technical Assistance}

Forestry consultants, county foresters, timber dealers and brokers, wood processing mills, Landowner Assistance Programs and county extension agents may be able to assist you with assessing your damages and determining your next steps. Telephone numbers for timber dealers, brokers and wood processing mills can be found in the Yellow Pages of your telephone book under "Timber". County foresters are employees of the Florida Division of Forestry (DOF) and are listed in the government pages of your telephone book and on the DOF Web site http://www.fl-dof.com/Help/county_forester/ index.html). County foresters also maintain lists of forestry consultants and logging companies that operate in your area. If you have access to the Internet, use your favorite search engine, such as Google $^{\mathrm{TM}}$, to find help. Key words such as "Florida forestry", "Florida timber buyers", "Florida foresters", and other similar terms will help narrow your search. Another source of timber buyers is the Florida Forestry Associations Web page www.floridaforest.org. Click on Loggers, and then go to Master Logger Search. Input your county as well as adjacent counties for a complete list of Master Loggers in your area. Landowners enrolled in a Landowner Assistance Program (LAP) should consult their LAP forester. Landowners that are not enrolled in a LAP might consider this a good time to become enrolled. There is no charge for LAP technical assistance. A private consultant can also help you evaluate your stand conditions and plan sales of the damaged timber. Other private consultants can be found through the Association of Consulting Foresters of America, Inc. Web page www.acf-foresters.com

Given the high demand for assistance in the coming months, property size, and more importantly, timber volume, will influence how much help you will be able to receive. It will be very difficult, if not impossible, to have a small volume of timber harvested. If a number of adjacent landowners are willing to work together to arrange for a salvage timber sale, then the combined timber volume may enhance the chances for hiring logging crews and receiving reasonable stumpage prices. 


\section{Assessing Damage}

\section{Timber}

The first critical step for planning salvage harvests or handling tax losses is to determine the extent and type of damage across your property. Using an aerial photo or map of your property, walk all the boundaries and throughout the stands (if you can do so safely) and note on the photo or map the locations of the major pockets and types of damage. Take pictures to show the actual property damage before any cleanup or salvage operations begin. The extent of tree damage and location, and average tree diameter, might influence your salvage decisions. At several locations throughout the damaged parts of your stands it will be important to count and record the numbers (or percentages) of trees that are undamaged or in one of the following categories:

\section{Uprooted hardwoods or pines}

2. Broken tops or major stems with less than four main live limbs left on the tree

3. Broken tops or major stems with four or more main live limbs left on the tree

\section{Severely bent pines}

5. Major wounds, more than 2 inches deep and/or over 1 square foot in size.

For both hardwoods and pines, if trees are reasonably vertical and have at least four main live limbs remaining on the tree (category 3 ) they will probably survive, although growth will likely be reduced until the crown redevelops. They can be retained for removal in a future thinning or final harvest, but continue to carefully monitor the trees through the next year for infestations of bark beetles, since the trees have been stressed and wounds are likely present.

Trees which are bent, broken (with three or fewer live limbs), or splintered (categories 2 and 4) probably have internal wood damage such as ring shake and pulled fibers and all or part of the tree may not be suitable for lumber or plywood but could be used for pulpwood, mulchwood or particleboard. Ring shake may be less of an issue if the trees have only been subject to winds in one direction; severe winds from alternating directions can lead to twisting and torque stresses. Broken stems, however, inevitably lead to some ring shake and pulled fibers. When merchandizing a section of the tree as solid wood product such as chip-n-saw, sawlog, or plylog, the logger often must start the log several feet past the break to avoid these defects.

Uprooted (category 1) and leaning trees are more likely to have undamaged wood, may dry out more slowly slower than broken trees, and could still be suitable for lumber if harvested within 2 to 3 months, before blue stain or decay fungi discolor the wood or wood-boring insects create holes in the trees. If major wounds (category 5) are extensive, pine bark beetles could threaten residual pine trees. Also wood borers and decay may be a problem soon and the trees should be harvested as soon as possible.

\section{Roads and Infrastructure}

Part of the damage assessment should focus on roads, fences, gates, stream crossings and any other structures on the property. If they are damaged you should note what needs to be done to maintain or repair them. You must have enough access to support 80,000 pound log trucks and the accompanying logging equipment. Again, pictures will prove very helpful for documenting expenditures and repairs.

\section{High Priority Problems}

Value of storm damaged timber decreases with time for a number of reasons: blue stain or decay fungi, wood borers, further losses from bark beetles, large volumes of wood on the market, and higher harvesting costs in damaged stands. Prompt action to assess timber and conduct salvage harvests should focus on the highest value timber (large diameters) which may only be useful for pulpwood, mulchwood or particleboard once stain and decay fungi or wood borers set in. Several factors influence the amount of time that it takes for wood to degrade from a solid wood product to a less valuable product such as pulpwood. Some factors include weather conditions, type of damage, and whether the timber is immediately dead or perhaps still initially alive after the storm event. As a general rule, damaged timber 
that could be sold for lumber or plywood should be harvested within two or three months.

\section{Potential for Insects, Disease or Wildfire}

The more severely the timber is damaged, the more likely is an attack by insects. Trees with less than three remaining limbs are most likely to be attacked as well as those that are bent, leaning, or scarred. The southern pine beetle (SPB) is the most serious threat to storm-weakened pine timber. This insect is capable of killing even healthy trees under favorable outbreak conditions. If such conditions occur, they will most likely be in late spring or summer next year. Cool winter temperatures and sufficient rainfall should reduce tree stress until next spring. Weakened pines emit a scent that is attractive to SPB, and once the beetles settle in, an infestation may engulf large areas of pine timber. An uncontrolled SPB infestation can kill hundreds of acres of pine timber in a relatively short time span. The other pine bark beetles (species of engraver or Ips beetles and the black turpentine beetle) also attack weakened, injured and stressed pines; and under more normal conditions, individual infestations seldom encompass more than 10-15 trees. These beetles usually attack scattered single trees, or two to three trees in a group. However, when stands of pine are suffering high stress, larger more extensive infestations can occur. Salvaging damaged trees, as soon after the storm as possible, is the best way to prevent pine bark beetle infestations.

Whether the standing timber is heavily damaged or not, branches, leaves and broken tops litter the forest floor after a storm, and become potential fuel for a wildfire the following spring. Bush-hogging, crushing, roller chopping or prescribed burning will help reduce those fuels.

\section{Decisions to Make}

Once you have assessed the damage you are in a much better position to determine whether you need to consider a salvage harvest or whether the stand has a sufficient number of healthy trees to recover on its own. The North Carolina Division of Forest Resources offered these guidelines in 2002, modified for Florida in this publication:
1. If there is only minor bending or leaning of merchantable-size trees with intact root systems, the trees will naturally recover, and it is probably best to wait and see before exploring salvage options.

2. If trees have only minor damage and the timber is still green and standing, dont rush to salvage; wait and see if they will naturally recover.

3. If less than 20 percent of the trees in your forest appear to be damaged, don't harvest the entire tract. If most of the damage is in one area or small pockets consider small clearcuts of those areas. If, instead, the damaged trees are scattered throughout the stand, leave it for a thinning operation when timber markets improve.

4. If the majority of the timber stand is broken down and salvage is needed, get professional guidance in finding a timber buyer.

5. Have patience during this time and use good business sense. Use the resources available to you to make sure you are getting all that your timber may be worth.

\section{Salvage the Stand}

If you determine that a salvage harvest is necessary, you should plan that harvest as soon as possible to best utilize the timber and redeem its value rather than let it go to waste and attract insects. The available salvage period varies according to the expected product but would not usually exceed 60-90 days. Sometimes, under certain conditions, the salvage period can exceed 90 days. The North Carolina State University Cooperative Extension Service's Forest Disaster Fact Sheet D-5 (Decision-making Guidelines for Storm-Damaged Trees, http://www.ces.ncsu.edu/nreos/forest/disaster/d5.html ) suggests that trees in damage categories 1,2, 4 and 5 (page 3) should be harvested as soon as possible. Harvest of trees with category 3 damage (broken tops, but major stems standing with four or more main live limbs) can be delayed to the next thinning or when timber markets improve. 
Timber salvage operations are more time consuming than regular harvesting, therefore the prices paid for the damaged timber will be lower than prices for standing timber. From a logging point of view, it takes two to three times as long to salvage one load of downed timber as it does to harvest a regular load of logs. As production times increase, so do logging costs, and these increases are especially noticeable if salvage operations are conducted separately for lumber versus pulpwood or mulchwood products. Thus, salvage harvests will be least costly if all products are merchandized at one time. Several other factors also influence salvage results. A broken tree may not be able to be converted to lumber or plywood and may have to be sold as pulpwood regardless of its size; with that in mind, salvage harvests for pulpwood can be delayed for up to six months. However, dead timber often dries out rapidly and has less dollar value when weight scaled. In fact, most mills will not accept timber when the bark is falling off the tree.

\section{What about Hardwoods?}

Hardwood trees that are standing and have even a small portion of the crown remaining will probably recover in time. Large hardwood trees that are uprooted should be removed, especially those near structures. Hardwood trees with large damaged areas on the trunk or large broken limbs may be infected with decay fungi which, after several years, will weaken a tree structurally and make the tree more susceptible to future wind damage. Damaged hardwood trees in residential areas that are not removed should be properly pruned to eliminate broken branches and branch stubs and promote rapid healing. Homeowners are reminded to contact their insurance agent concerning the loss of shade trees, pines or hardwoods, or property damage caused by falling trees.

\section{Tax Considerations}

\section{Timber Casualty Loss Deductions}

If you have trees that have blown over, had tops severed, trunks split or other damage which stopped growth or resulted in tree death, you may be eligible to file for casualty loss deductions for income tax purposes (Greene 2004). To be allowed as a casualty deduction, a loss to one's timber must be caused by natural or other external factors acting in a sudden, unexpected and unusual manner. A sudden event is one that is swift, not gradual or progressive. An unexpected event is one that is ordinarily unanticipated and one that you do not intend. Hurricanes should fit those IRS definitions.

Unfortunately most timber casualty losses are limited to the adjusted basis of the timber. The general rule is that the amount of deductible loss is the lesser of the decrease in the fair market value of the timber or the adjusted basis (minus any income received from a salvage operation and/or any insurance proceeds). Part of the casualty loss deduction depends on how the timber is held, the type of property and how it is used, the timber's age and merchantability and other nontimber asset income and expenses that will influence this deduction. It is extremely important to work this out with your tax advisor and/or a knowledgeable consulting forester. Be sure to ask your forester if he or she has the necessary expertise to advise you in this area.

To claim a loss deduction, you must make an authentic attempt to sell and salvage the damaged timber and keep records of your attempt to do so. You must also identify the damaged or destroyed object or property. For timber, this identification is expressed in terms of the specific units of volume destroyed such as board feet, cords, cubic feet, etc. However, several recent court cases led the IRS to issue Revenue Ruling 99-56 which allows loss deductions to be calculated on a "block" method (Greene 2004).

When you salvage your timber, be sure to get a written contract to protect the residual trees and your forest land. Identify what type of trees are to be salvaged such as broken, downed or bent at certain angles and what trees are to be left on the site if any. Finally, determine how you will be paid for the salvaged timber and include this information in the contract. For more information on marketing timber and timber sale contracts, see the following websites: http://edis.ifas.ufl.edu/FR130; http://msucares.com/pubs/publications/p1855.htm; http://warnell.forestry.uga.edu/warnell/service/library/ index.php3?docID=11. 
If your receipts from a salvage sale are greater than your adjusted basis in the timber, you will have a taxable gain, which is a separate transaction from the casualty loss deduction, and must be reported as a gain. However, the gain and tax on it can be postponed by using it to purchase qualifying replacement property within an allowable replacement period.

Casualty losses should be reported to the IRS with Federal Form 4684, and as a deduction on your tax return for the year the loss takes place. If the casualty loss resulted from a Presidentially declared disaster (as was the case in most Florida counties), you can choose to deduct the loss on an original or amended tax return for the year immediately before the year the disaster took place (Greene 2004). It is also recommended that you make sure you get documentation of the date of the casualty, the location of the damage, property appraisals, and if possible, photographs of the property before and after the disaster occurred.

\section{Young Plantations}

If you have maintained your records of costs incurred in young plantations, you may also be able to receive casualty loss deductions for those stands. The amount that you may claim is calculated by dividing the costs for establishing the stand to date by the total number of acres in plantation. The value per acre, multiplied by the number of acres destroyed is the amount you can claim.

\section{Non-Business Casualty Losses}

You may also deduct damage sustained to personal property, such as downed trees in your yard. To do so you need all the documentation required for business casualty losses. The amount which you may claim is based on the fair market value (FMV) of your property. Once you have calculated the decrease in FMV caused by the loss, you need to subtract $\$ 100.00$ from the total loss for each event as well as subtract $10 \%$ of your adjusted gross income from your combined losses from all events during the year. Also, if you receive insurance or other reimbursements (such as loan forgiveness), these need to be subtracted from the amount of loss that you calculate for deduction.
A certified public accountant, a tax attorney or a knowledgeable consulting forester with a good tax background are the best options for high quality tax information and assistance.

Timber Tax and Financial Assistance $\underline{\text { Information Sources }}$

Haney, H.L., W.L. Hoover, W.C. Siegel, and J.L. Greene. 2001. Forest Landowners' Guide to the Federal Income Tax. Agriculture Handbook 718. U.S. Department of Agriculture, Forest Service, Washington, D.C. 157 p.

National Timber Tax Web site. http://www.timbertax.org. This site has information you will need in order to file casualty loss deductions.

http://www.irs.gov/index.html. This Web site includes information for filing for tax deductions as well as the appropriate forms. The IRS toll-free number for general tax questions is 1-800-829-1040.

http://www.fs.fed.us/r8/spf/coop/taxation/ Web site provides links to a number of tax-related documents and articles, including Agriculture Handbook 718; it also includes a sample timber sale contract.

http://disasterhelp.gov. This Web site includes information on all federal assistance programs.

\section{Management Plan Revisions}

Once you have dealt with damage assessment, salvage operations and financial issues, one more important post-storm step will be to revise your management plan to reflect the changes. Regeneration plans, harvest schedules, and activities to minimize future potential problems will undoubtedly need to be reviewed and updated, especially for those activities that will be necessary in the next few years and for which technical and financial assistance might become available. The county or consulting forester who helped you prepare your last plan will be your best first contact for this process. If you do not have a current management plan, now may be a good time to develop one as you deal with the changes before you. 


\section{Additional Sources of Assistance}

If you have trees, bushes, or vines that provide an annual crop (such as grapes or fruit / nut trees), or if you have rangeland or crop land and are interested in receiving federal assistance, contact your local Farm Service Agency office: http://disaster.fsa.usda.gov/fsa.asp, or try one of the following websites:

http://www.florida-agriculture.com/special/ federal_programs.htm. This Web site has a listing of all federal programs that deal with crop losses.

http://www.fl-dof.com_and http://www.ces.ncsu.edu/nreos/forest/disaster.html. The Florida Division of Forestry and North Carolina State University Forestry Extension Web sites have information on pruning or removing damaged trees, as well as information for replanting.

\section{References}

Barry, P.J., C. Doggett, R.L. Anderson and K.M. Swain, Sr. 1998. How to evaluate and manage storm-damaged forest areas. USDA Forest Service Southern Region Management Bulletin R8 MB 63.

College of Natural Resources, North Carolina State University, Web site http://www.ces.ncsu.edu/nreos/forest/disaster.html

contains fact sheets for a variety of topics related to storm damage and response.

Greene, John. 2004. Loss deductions for timber damaged or destroyed by a natural disaster. http://www.fs.fed.us/r8/spf/documents/ losssummary.pdf 